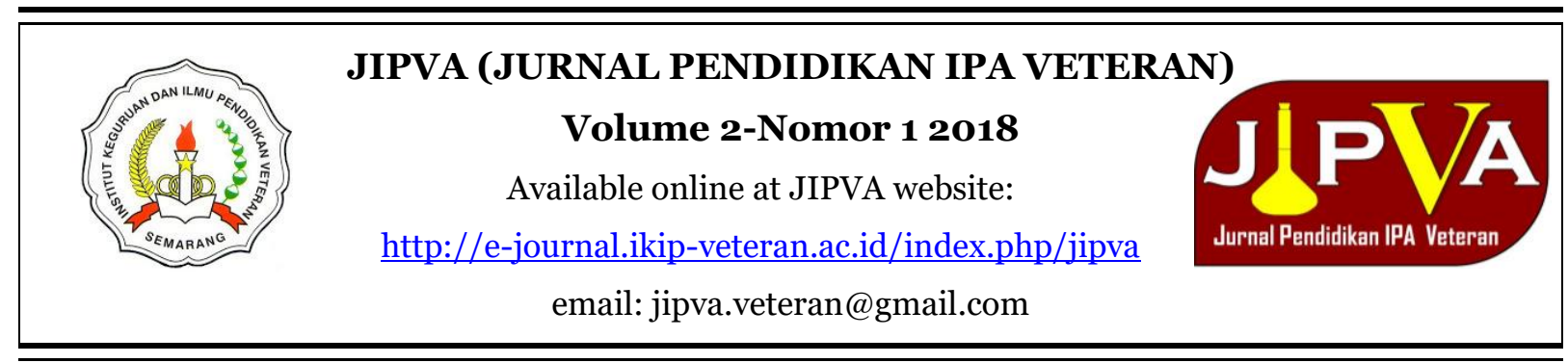

\title{
KARAKTER PEDULI LINGKUNGAN SISWA SMP DITINJAU DARI TINGKATAN KELAS DAN GENDER
}

Lovely Ezverenzha L*, Risya Pramana S., Agna Sulis K

Program Studi Pendidikan Biologi Universitas Kristen Satya Wacana

*email : lovely_ezveranzha@yahoo.com

\begin{abstract}
Abstrak
Penelitian survei dengan metode kuantitatif deskriptif ini bertujuan untuk mengetahui karakter peduli lingkungan siswa SMP ditinjau dari tingkatan kelas dan untuk mengetahui hubungan antara gender dan tingkatan kelas terhadap karakter peduli lingkungan siswa SMP. Siswa pada tingkatan kelas VII dan IX menunjukkan karakter peduli lingkungan yang lebih baik dibandingkan kelas VIII berdasarkan dari kategori penilaian pada instrumen New Ecological Paradigm. Untuk kategori Sangat Baik kelas VII dan IX lebih tinggi (22.22\% dan 27.27\%) sedangkan kategori Tidak Baik, kelas VII dan IX lebih rendah dari kelas VIII $(5.56 \%, 9.09 \%, 9.52 \%)$. Hubungan gender dan tingkatan kelas dengan uji Pearson diperoleh satu hasil korelasi yang signifikan yaitu antara perempuan kelas VIII dengan perempuan kelas IX ( $\mathrm{r}=0.798$; Sig.0.017 < 0.05). Berdasarkan hasil penelitian disimpulkan tingkatan kelas lebih berhubungan dengan karakter peduli lingkungan siswa daripada faktor gender, ditunjukkan dari aktivitas siswa yang tidak memandang gender dalam menjaga keasrian lingkungan sekolahnya.
\end{abstract}

Kata kunci: karakter peduli lingkungan, New Ecological Paradigm, tingkatan kelas, gender

\section{ENVIRONMENTAL AWARENESS OF JUNIOR HIGH SCHOOL STUDENTS IN TERMS OF GRADE AND GENDER}

\begin{abstract}
This survey research by quantitative descriptive method was conducted with purpose to find out the environmental awareness of junior high school students in terms of grade and also to find out the correlation between gender and grade for students attitude towards environments. The analysis and interpretation data of New Echogical Paradigm instrument found that the students on $7^{\text {th }}$ and $9^{\text {th }}$ grade represent the best attitude towards environments more than $8^{\text {th }}$ grade. For Very Good category $7^{\text {th }}$ and $9^{\text {th }}$ grade have higher percentage $(22.22 \%$ and $27.27 \%)$, while Not Good category, $7^{\text {th }}$ and $9^{\text {th }}$ grade are lower than $8^{\text {th }}$ grade $(5.56 \%, 9.09 \%, 9.52 \%)$. The correlation between grade and gender tested by Pearson test proved that it has significant correlation between female students on $8^{\text {th }}$ and $9^{\text {th }}$ grade ( $r$ $=0.798 ;$ Sig.0.017 < 0.05). Based on result, we can concluded that the grade level is more related than gender for students' environmental awareness, showed by students maintaining school sanitation activity.
\end{abstract}

Keywords: environmental awareness, new ecological paradigm, grade level, gender 


\section{PENDAHULUAN}

Informasi mengenai kondisi lingkungan di Indonesia sampai saat ini cukup memperihatinkan, meskipun sudah banyak gerakan yang dimunculkan oleh beberapa kelompok peduli lingkungan bahkan dari program-program pemerintah untuk melestarikan dan menjaga lingkungan. Disadari atau tidak semua aktivitas negatif terhadap lingkungan diakibatkan oleh ulah manusia yang tidak menghiraukan ajakan pemerintah dan cenderung mengeksploitasi alam tanpa perhitungan.

Implikasinya adalah pemanasan global, perubahan iklim, kepunahan spesies, berkurangnya sumber daya ikan, polusi udara dan persediaan air (Kalantari dan Asadi, 2010). Cara yang efektif dalam upaya mengubah perilaku manusia terkait usaha melestarikan lingkungan hidup adalah melalui pendidikan di sekolah. Pendidikan peduli lingkungan hidup di sekolah dapat diterapkan melalui kegiatan pembelajaran atau bahkan di cantumkan dalam peraturan sekolah, dengan demikian anak akan menjaga sikapnya tersebut ketika berada dalam keluarga. Sikap yang dimaksud dalam konteks ini adalah mengacu kepada karakter. Karakter peduli lingkungan berakar dari konsep diri seseorang dan seberapa jauh individu tersebut memandang dirinya sebagai bagian integral dari lingkungan alam (Muhammad et al. 2014). Sejalan dengan pernyataan Muhammad, Hamzah (2013) menjelaskan bahwa kepedulian terhadap lingkungan hidup merupakan wujud karakter individu yang direfleksikan dalam perilakunya. Karakter ini tidak diperoleh manusia sejak lahir, namun harus dibentuk sehingga dapat berkelanjutan. Karakter hanya dapat dibentuk secara akademis, dan tentu jawabannya hanya satu, yaitu "pendidikan".

Secara historis pemerintah melalui Kementrian Pendidikan pernah memulainya pada tahun 1984 dengan memasukkan materi lingkungan hidup ke dalam mata pelajaran tingkat menengah umum dan kejuruan. Berkembang kemudian pada kurikulum tahun 2006 (Kurikulum Tingkat Satuan Pendidikan) dan juga kurikulum 2013. Pendidikan lingkungan hidup selain terintegrasi ke mata pelajaran IPA (SD, SMP) dan Biologi (SMA), juga diberikan peluang menjadi mata pelajaran tersendiri melalui mata pelajaran muatan lokal (mulok) (Ahzar et al. 2015).

Namun kenyataan yang terlihat di lapangan masih banyak pelajar yang kurang terlibat dalam menjaga kelestarian lingkungan sekolahnya, bahkan pada saat sedang tidak berada di lingkungan sekolahnya. Pernyataan ini muncul karena masih ditemukan pelajar yang membuang sampah sembarangan seperti di laci meja atau di lantai kelas meskipun sudah tersedia tempat sampah.

Penelitian terkait karakter peduli lingkungan kepada peserta didik, salah satunya dilakukan oleh Kusman dkk, (2006) tentang Environmental Beliefs and Attitudes: An Analysis of Ecological Affinit in Secondary Students in Indonesia. Kusman et al, melakukan pengujian terhadap efek pembelajaran biasa yang terjadi di kelas mengenai lingkungan kepada siswa di kota dengan siswa di pinggiran kota, dengan efek pembelajaran aktif yang diterima siswa di kota dengan siswa di pinggiran kota melalui praktik penelitian atau kerja kelompok. Hasil penelitian menunjukkan bahwa pembelajaran sains yang aktif memberikan pengaruh signifikan dalam sikap siswa di kota, untuk menjaga kualitas dari 
lingkungan ketika mereka diberikan praktik lapang dan kerja kelompok pembelajaran di kelas.

Fakta ini menunjukkan bahwa meskipun dalam mata pelajaran yang sudah diintegrasikan dengan materi lingkungan hidup dan bahkan diberikan mata pelajarannya sendiri yaitu Mulok masih kurang dalam memastikan sikap peduli lingkungan pada anak (peserta didik) akan dipraktikkan secara keseluruhan dalam aktivitas mereka.

Selain pendidikan lingkungan hidup yang didapat di sekolah beberapa peneilitian pun menyebutkan bahwa faktor gender juga memberikan pengaruh terhadap karakter seseorang dalam menjaga lingkungan seperti yang diteliti oleh Suhardin (2016) tentang pengaruh perbedaan jenis kelamin terhadap kepedulian lingkungan siswa SMA, dan diperoleh hasil yaitu siswa wanita memiliki kepedulian lebih dibandingkan siswa pria terhadap lingkungan. Penelitian terkait gender dengan pengetahuan lingkungan juga dilakukan oleh Purnomo Priyo (2014) yang meneliti sikap peduli lingkungan dari mahasiswa UMS, dan hasil yang didapatkan yaitu bahwa gender memoderasi pengaruh pengetahuan lingkungan terhadap perilaku peduli lingkungan mahasiswa.

Karakter peduli lingkungan yang dimaknai sebagai bagian dari kehidupan sosial membuat beberapa peneliti mulai terlibat dalam menciptakan skala sikap terhadap lingkungan. Dunlap adalah salah satu peneliti yang mencetuskan skala sikap New Ecological Paradigm (NEP) yang menjadi alat ukur dalam penelitian ini. Instrumen NEP (New Ecological Paradigm) memiliki 15 item uji dan terbagi menjadi 5 item ekologi (pandangan manusia sebagai bagian alam) dan 7 item antroposentris (pandangan manusia sebagai penguasa alam) (2000).

Berdasarkan pernyataan-pernyataan di atas, penelitian ini merumuskan dua masalah yaitu apakah terdapat hubungan tingkatan kelas dengan karakter peduli lingkungan siswa? dan bagaimana hubungan antara tingkatan kelas dan gender dengan karakter peduli lingkungan siswa SMP kelas 7-9?

Untuk menjawab kedua rumusan masalah ini maka peneliti membuat dua tujuan penelitian yaitu untuk mengetahui karakter peduli lingkungan siswa SMP ditinjau dari tingkatan kelas dan gender dan menganalisis hubungan antara gender dan tingkatan kelas terhadap karakter peduli lingkungan siswa SMP.

\section{METODE}

\section{Jenis Penelitian}

Penelitian ini adalah penelitian survei dengan metode kuantitatif deskriptif melalui analisis korelasi. Korelasi yang akan dilihat dalam penelitian ini adalah korelasi gender terhadap karakter peduli lingkungan anak serta korelasi peran keluarga terhadap karakter peduli lingkungan anak. Analisis korelasi ini nantinya akan menunjukkan aspek yang kuat terhadap karakter anak.

Penelitian survei yang deskriptif ini dimaksudkan untuk pengukuran yang cermat terhadap hubungan gender dan peran keluarga dalam menciptakan karakter anak terhadap lingkungan hidup. Penelitian ini menggunakan desain penelitian survei kategori cross-sectional (Sudarsono, 2013). Desain cross-sectional dilakukan terhadap kelompok responden (sampel) dalam jangka waktu yang relatif pendek. 


\section{Waktu dan Tempat Penelitian}

Penelitian survei ini dilaksanakan di SMP X Salatiga, Jawa Tengah. Pelaksanaan penelitian ini dilaksanakan pada bulan September-November 2017 di semester 1 tahun ajaran 2017/2018.

\section{Target/Subjek Penelitian}

Subjek penelitian dalam penelitian survei ini adalah siswa SMP kelas VII, VIII, dan IX. Total siswa kelas VII berjumlah 18 dengan 12 putera dan 6 puteri, total siswa kelas VIII berjumlah 21 dengan 11 putera dan 10 puteri, total siswa kelas IX berjumlah 22 dengan 10 putera dan 12 puteri.

\section{Prosedur}

Prosedur penelitian survei ini menggunakan desain cross-sectional dengan beberapa tahapan yaitu:

a. formulasi masalah penelitian.

b. menyusun hipotesis.

c. Menentukan variabel-variabel penelitian. Variabel bebas dan variabel terikat pada penelitian ini antara lain: gender dan tingkatan kelas sebagai variabel bebas, sedangkan karakter peduli lingkungan sebagai variabel terikat.

d. Menyusun instrument.

e. Menentukan sampel dan teknik sampling

f. Uji validitas dan reliabilas. Validitas dan Reliabilitas instrumen menggunakan cara pengujian konstruk dan isi, dimana itemitem pada instrumen akan dianalisis terlebih dahulu oleh ahli. Setelah dianalisis ahli, instrumen dapat diujicoba pada sampel populasi (Azwar, 2012).

g. Mengumpulkan data.

h. Mengolah dan menganalisis data.

i. Membuat kesimpulan dan rekomendasi.

\section{Data, Intrumen, dan Teknik Pengumpulan Data}

Untuk dapat memperoleh data yang valid maka peneliti menggunakan 3 teknik pengumpulan data, yaitu wawancara, angket NEP (adaptasi dari Dunlap, 2000) dan dokumentasi. Wawancara dilakukan terhadap 5 orang anak dari maisng-masing tingkatan kelas biak itu siswa laki-laki maupun siswa perempuan.

Instrumen adaptasi NEP ini terbagi menjadi 6 aspek dengan 21 pernyataan. 6 aspek, yaitu batas pertumbuhan, antiantroposentrisme, keseimbangan alam, antieksepsionalisme, krisis lingkungan, dan peran keluarga.

\section{Teknik Analisis Data}

Proses penentuan atas jawaban responden (siswa SMP) dilakukan dengan membuat klasifikasi dan kategori yang cocok tergantung pada opini responden dalam instrumen. Perhitungan skoring dilakukan dengan menggunakan skala 4 Likert, kemudian dikonversikan seperti pada tabel.1 di bawah ini (Subali, 2012).

Tabel 1. Konversi Skor Nilai Skala 4

\begin{tabular}{lcl}
\multicolumn{1}{c}{ Interval } & Nilai & \multicolumn{1}{c}{ Kategori } \\
\hline $\mathrm{X} \geq \mathrm{Yi}+1$. Sbi & A & Sangat Baik \\
\hline $\mathrm{Yi}+1$. Sbi $>\mathrm{X} \geq \mathrm{Yi}$ & $\mathrm{B}$ & Baik \\
\hline $\mathrm{Yi}>\mathrm{X} \geq \mathrm{Yi}-1$. Sbi & $\mathrm{C}$ & Cukup \\
\hline $\mathrm{X}<\mathrm{Yi}-1$. Sbi & $\mathrm{D}$ & Tidak Baik \\
\hline
\end{tabular}

Analisis hubungan tingkatan kelas dan gender terhadap karakter peduli lingkungan siswa SMP kelas VII - IX berdasarkan analisis regresi linier berganda menggunakan software SPSS 16.0. 


\section{HASIL DAN PEMBAHASAN}

Pada tabel 2. ditunjukkan persentase karakter peduli lingkungan kelas VII, VIII, dan IX yang diperoleh dari jumlah pemberian kategori (sangat baik, baik, cukup dan tidak baik) pada lembar angket NEP oleh responden (siswa SMP) berdasarkan tingkatan kelas. Pemberian kategori penilaian menggunakan analisis konversi skala empat Likert (mean dan standar deviasi).

Tabel 2. Persentase Karakter Peduli

Lingkungan Berdasarkan Tingkatan Kelas

\begin{tabular}{ccc}
\hline Kelas & Kategori & Total $(\boldsymbol{\%})$ \\
\hline VII & SB & 22.22 \\
& B & 38.89 \\
& C & 33.33 \\
& TB & 5.56 \\
\hline VIII & SB & 19.04 \\
& B & 38.09 \\
& C & 33.33 \\
& TB & 9.52 \\
\hline IX & SB & 27.27 \\
& B & 27.27 \\
& C & 36.36 \\
& TB & 9.09 \\
\hline
\end{tabular}

Keterangan:

SB : Sangat baik, B : Baik, C : Cukup, TB : Tidak baik

Hasil persentase untuk kategori Sangat Baik pada tingkatan kelas VII - IX oleh siswa SMP secara berurutan yang paling banyak memberi kategori ini adalah dari kelas IX dan kelas VII diikuti oleh kelas VIII dengan persentase $27.27 \%$ (6 orang dari 22 siswa), $22.22 \%$ (4 orang siswa dari 18 siswa), dan 19.04 (4 orang dari 21 siswa). Pada kategori penilaian Baik tingkatan kelas VII - IX persentase paling tinggi yaitu pada kelas VII $38.89 \%$ (7 orang siswa dari 18 siswa) dan VIII $38.09 \%$ (7 siswa dari 21 siswa), sedangkan kelas IX $27.27 \%$ (6 siswa dari 22 siswa). Kategori Cukup dengan total persentase terbanyak adalah pada kelas IX $36.36 \%$ (8 orang dari 22 siswa) dan kelas VIII $33.33 \%$ (7 orang dari 21 siswa), sedangkan kelas VII $33.33 \%$ (6 orang dari 18 siswa). Persentase penilaian untuk kategori Tidak Baik dengan total terbanyak adalah kelas VIII $9.52 \%$ (2 orang dari 21 siswa) dan kelas IX $9.09 \%$ (2 orang dari 22 siswa), sedangkan total persentase terendah ada pada kelas VII $5.56 \%$ (1 orang dari 18 siswa).

Dari keempat kategori pernilaian berdasarkan skala Likert untuk instrumen lembar angket adaptasi dari NEP (New Ecological Paradigm) yang telah dinilai oleh siswa SMP berdasarkan tingkatan kelas, menunjukkan bahwa kelas VII dan IX untuk penilaian kategori Sangat Baik lebih tinggi dari kelas VIII, kategori Baik kelas VII dan VIII lebih tinggi dari kelas IX, kategori Cukup kelas VII dan VIII lebih sedikit persentasenya dari kelas IX, dan kategori Tidak Baik kelas VII dan IX lebih sedikit persentasenya dari kelas VIII. 


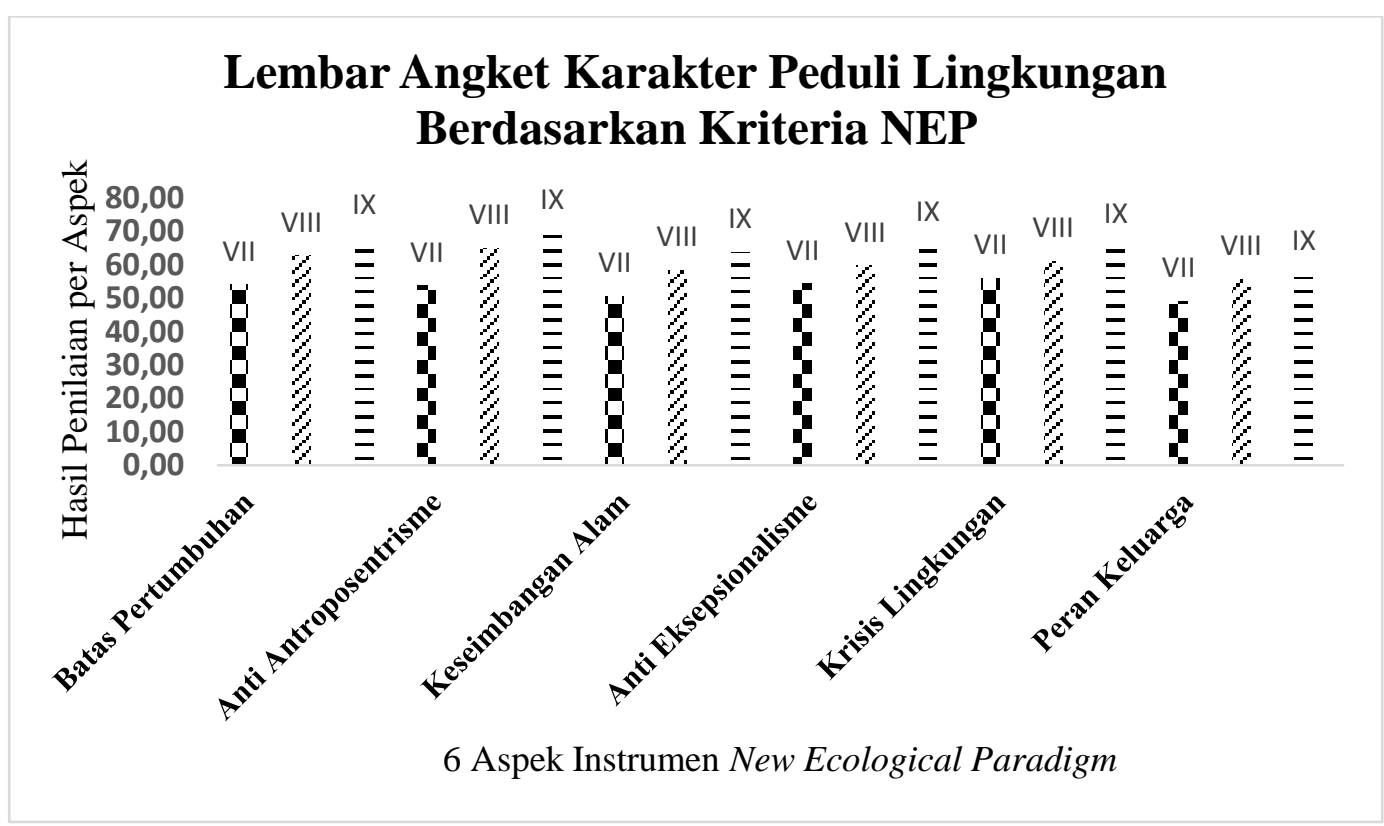

Gambar 1. Histogram Rerata Penilaian Siswa SMP Kelas VII, VIII, dan IX Terhadap 6 Aspek NEP

Nilai per-diagram diperoleh dari rata-rata jumlah pernyataan tiap indikator oleh siswa dari kelas tujuh, delapan, dan sembilan. Jika merujuk pada 6 indikator NEP terkait hubungan tingkatan kelas dengan karakter peduli lingkungan siswa SMP, indikator pertama yaitu Batas Pertumbuhan untuk kelas VII, VIII dan IX secara berurutan diperoleh nilai rerata 54.00, 62.67, dan 68.00, kemudian indikator Anti-Antroposentrisme yaitu 53.67, 65.00, dan 69.33. Keseimbangan Alam dengan rata-rata per kelas secara berurutan 50.67, 58.33, 63.67, AntiEksepsionalisme 54.33, 59.67, 66.00, Krisis Lingkungan 56.00, 61.00, 65.33 dan Peran Keluarga 49.167, 55.67, 57.17.

Hasil dalam gambar 1 di atas, dari enam indikator angket NEP untuk tingkatan kelas yang pendapat siswanya terkategori Baik pada keseluruhan aspek NEP berdasarkan rata-rata hasil penilaian adalah kelas IX. Hasil diagram untuk tingkatan kelas menunjukkan bahwa semakin tinggi tingkatan kelas maka penilaian siswa terhadap 6 aspek NEP semakin meningkat.

Jika pada tingkatan kelas menunjukkan kelas VII dan IX sebagai tingkatan kelas yang kepeduliannya pada lingkungan lebih tinggi dari kelas VIII maka untuk mendukung data tersebut hasil rerata penilaian gender dari masingmasing kelas dimasukkan dalam hasil penelitian ini untuk membuktikan hasil pada tabel dan histogram tingkatan kelas. Hasilnya tertera pada tabel 3 . berikut.

Tabel 3. Rerata Penilaian Lembar Angket NEP Dari Gender

\begin{tabular}{cccc}
\hline \multirow{2}{*}{ Gender } & \multicolumn{3}{c}{ Rerata Aspek per Gender } \\
& \multicolumn{3}{c}{$(\overline{\boldsymbol{x}})$} \\
\cline { 2 - 4 } & VII & VIII & IX \\
\hline Laki-Laki & 61.3333 & 59.308 & 61.9167 \\
\hline Perempuan & 60.8333 & 60.375 & 50.700
\end{tabular}

Pada kelas VII dan kelas IX nilai rerata siswa wanita lebih kecil dari siswa laki-laki dengan nilai secara berurutan 60.83 dan 61.33 untuk kelas IX 59.700 
dan 61.9167 sehingga berdasarkan hasil konversi rata-rata siswa perempuan kelas VII dan IX memberikan penilaian Cukup sedangkan siswa laki-laki memberi penilaian Baik terhadap 21 pernyataan terkait lingkungan alam dalam angket sikap NEP. Pada Kelas VIII sebaliknya, untuk siswa perempuan memberikan penilaian Baik sedangkan siswa laki-laki Cukup dengan nilai purata secara berurutan yaitu 60.375 dan 59.308 .

Berdasarkan hasil pada tabel persentase dan rerata kepedulian siswa SMP terhadap lingkungan maka kelas VII dan kelas IX merupakan kelas yang lebih menunjukkan kepeduliannya pada lingkungan.

Pengujian hipotesis penelitian menggunakan analisis korelasi dengan program SPSS 16.0. Model analisis yang digunakan adalah regresi linier sederhana dengan memilih hasil pada tabel Model Summary dan tabel Anova dengan tujuan untuk mengetahui signifikan karakter peduli lingkungan siswa dengan gender setiap tingkatan kelas.

Berdasarkan hasil analisis diperoleh nilai korelasi 0.54 yang dapat diinterpretasikan bahwa hubungan gender pada setiap tingkatan kelas terhadap karakter peduli lingkungan berada pada kategori cukup (Sudjana, 2005). Tabel uji signifikan (Anova) yang digunakan untuk menentukan taraf linieritas dari regresi dengan ketentuan jika nilai Sig $<0.05$. Dari tabel Anova diperoleh nilai Sig. $0.802>0.05$. Dengan demikian model persamaan regresi berdasarkan data penelitian adalah tidak signifikan, atau dapat disimpulkan bahwa gender memberikan berhubungan tidak signifikan terhadap karakter peduli lingkungan siswa SMP.

Model analisis correlations bivariate dengan prosedur uji Pearson digunakan untuk mendukung hasil analisis regresi linier dengan tujuan untuk mengetahui hubungan tingkatan kelas (VII-IX) dan gender terhadap kepedulian lingkungan berdasarkan hasil penilaian siswa pada lembar angket NEP (New Ecological Paradigm). Hasil uji Pearson didapatkan data sebagai berikut; perempuan kelas VII berhubungan secara positif dengan laki-laki kelas VII dalam kategori korelasi lemah sebesar 0.242 $(\mathrm{r}=0.242)$ meskipun berkorelasi positif namun hubungannya tidak siginifkan karena nilai signifikan korelasi siswa kelas VII $0.644>0.05$ yang berarti tidak ada korelasi antara laki-laki dan perempuan kelas VII terhadap perilaku peduli lingkungan mereka sedangkan siswa laki-laki VII berhubungan secara positif juga dengan laki-laki kelas IX dalam kategori kuat sebesar 0.433, namun hubungannya tidak signifikan $(385>0.05)$.

Berbeda dengan kelas VII yang meskipun berkorelasi lemah antara lakilaki dan perempuannya dalam hal kepedulian lingkungan tapi masih memiliki hubungan yang positif, kelas VIII berdasarkan uji Pearson tidak menunjukkan korelasi yang positif.

Perempuan kelas VIII berkorelasi sangat kuat dengan perempuan kelas IX dan kuat dengan laki-laki kelas IX, dengan nilai korelasi 0.798 dan 0.512 sedangkan dengan teman sekelas lakilaki kelas VIII justru tidak berkorelasi. Nilai korelasi antara perempuan kelas 
VIII dengan perempuan kelas IX sangat kuat sehingga berefek pada nilai signifikansi, yaitu $0.017<0.05$ dan disimpulkan bahwa ada korelasi yang signifikan antara tingkatan kelas dan/atau gender terhadap karakter peduli lingkungan khususnya untuk perempuan kelas VIII dan IX.

Korelasi selanjutnya yaitu laki-laki kelas VII tidak memiliki korelasi positif dengan teman sekelasnya namun memiliki korelasi dengan perempuan kelas IX yang positif dengan kategori lemah, nilai $\mathrm{r}=0.215$ nilai signifikansinya lebih besar dari 0.05 sehingga hipotesis korelasinya menjadi tidak signifikan.

Karakter peduli lingkungan siswa tidak bisa muncul begitu saja tanpa adanya usaha dalam diri atau peranan lingkungan sosial seperti di sekolah, keluarga, dan teman bermain.

Dari hasil penelitian yang terbagi menjadi persentase tingkatan kelas, rerata karakter peduli lingkungan berdasarkan gender tiap tingkatan kelas, histrogram rerata penilaian siswa SMP terhadap 6 indikator angket NEP dan analisis statistik, dapat dijelaskan bahwa tingkatan kelas ada hubungannya dengan karakter peduli lingkungan siswa SMP sedangkan gender tidak begitu besar hubungannya dengan karakter peduli lingkungan siswa seperti yang ditunjukkan pada uji regresi linier berganda dimana hubungan gender masing-masing tingkatan kelas terhadap penilian instrumen menghasilkan korelasi yang cukup namun tidak bersignifikan, hal ini dibuktikan dengan uji Pearson, yaitu hanya pada perempuan kelas VIII dengan perempuan kelas IX yang berkorelasi sangat kuat dan saling berhubungan (nilai korelasi $\mathrm{r}=0.798$ dan signifikan $0.017<0.05)$ sedangkan gender dari kelas lain tidak berkorelasi signifikan. Ini menunjukkan bahwa perilaku peduli lingkungan tidak lagi dipengaruhi oleh gender yang merupakan status sosial tetapi oleh pengetahuan dan perkembangan diri siswa. Pengetahuan yaitu keyakinan yang mendorong perasaan positif atau negatif terhadap suatu objek (Septian, 2016).

Perilaku peduli lingkungan yang ditampilkan siswa SMP berdasarkan dari hasil diasumsikan masih dalam tahap awal pengembangan karakter dari pihak sekolah artinya terdapat peraturanperaturan yang harus diikuti oleh siswa terkait kepedulian terhadap lingkungan atau dikarenakan perkembangan zaman yang sudah dilengkapi dengan teknologi.

Dari hasil penelitian menunjukkan bahwa siswa SMP yang diuji kepeduliannya terhadap lingkungan, tidak berdasarkan pada gender sebagai status sosial siswa namun lebih pada pengetahuan siswa tiap tingkatan kelas yang didapat dari sekolah atau melalui teknologi. Seperti yang dinyatakan oleh Mujahidah (2015) bahwa karakter peduli lingkungan tidak dapat muncul secara lahiriah namun muncul dalam diri seseorang melalui pengetahuan yang didapat.

Sehingga hasil pengujian pada siswa SMP ini menunjukkan bahwa karakter siswa berdasarkan penilaian mereka untuk 21 item pernyataan instrumen NEP tidak dipengaruhi oleh status sosial mereka namun oleh pengetahuan yang berbeda tiap tingkatan kelas. Meskipun gender tidak begitu memberikan pengaruh dalam tinjauan 
hubungan terhadap karakter peduli lingkungan, tetapi terdapat korelasi yang siginifikan antara perempuan kelas VIII dengan perempuan kelas IX dengan nilai korelasi $\mathrm{r}=0.798$ dan signifikan $0.017<$ 0.05. Ini menunjukkan bahwa terdapat hubungan yang signifikan antara gender dengan tingkatan kelas terhadap peduli lignkungan siswa namun hanya pada perempuan kelas VIII dan kelas IX sedangkan pada gender laki-laki dan perempuan kelas lain tidak berkorelasi signifikan.

Korelasi yang signifikan antara perempuan kelas VIII dan IX ini dapat dibuktikan juga dari hasil wawancara. Terdapat kesamaan jawaban yang disampaikan oleh siswa perempuan dari kedua kelas berbeda ini.

Beberapa diantaranya yaitu terkait dengan batas pertumbuhan (bumi sudah tidak mampu lagi untuk menampung populasi manusia yang telah melewati batas) dan anti antroposentrisme (tumbuhan dan hewan memiliki hak yang sama dengan manusia untuk bertahan hidup) dengan jawaban yang diberikan siswa pada saat wawancara yaitu pernyataan bahwa bumi masih memiliki banyak tempat untuk didiami karena ada populasi yang meninggal dan lahir, serta tumbuhan dan hewan memiliki hak yang sama dengan manusia karena merupakan ciptaan Tuhan.

Papalia et al (2008) menyatakan bahwa keterlibatan remaja dengan teman sebayanya, selain menjadi sumber dukungan emosional yang penting selama masa remaja, juga sekaligus menjadi sumber tekanan bagi remaja. Artinya bahwa teman sebaya memiliki hubungan yang kuat dalam membentuk karakter anak. Selanjutnya pendidikan di sekolah yang berarti karakter anak terhadap lingkungan alam tidak bisa dilakukan secara parsial saja tetapi harus bisa membawa anak ke pengenalan nilai secara kognitif, penghayatan nilai secara afektif, dan pengalaman nilai secara nyata (Mujahidah, 2015). Selain faktor teman sebaya dan budaya sekolah, perkembangan diri siswa juga menjadi faktor yang menentukan karakter peduli lingkungan siswa (Izzaty et al, 2007).

Dari hasil ini dapat diketahui bahwa tingkatan kelas ternyata mempengaruhi persepsi siswa terkait lingkungan alam setelah menilai 21 pernyataan dalam angket NEP, namun hal ini belum dapat menunjukkan karakteristik siswa terhadap lingkungan alam. Siswa dihadapkan pada beberapa kasus untuk mewakili karakter peduli lingkungan siswa dengan didasarkan pada beberapa indikator yang digabung lalu diterapkan sesuai dengan kondisi lingkungan sekolah uji. Beberapa indikator yang telah digabung kemudian disusun menjadi 2 indikator berdasarkan pada penelitian yang dilakukan oleh Tamara (2016), yaitu penerimaan (receiving) dan partisipasi (responding).

Dari penggabungan keenam indikator NEP ini, pada tahap penerimaan (receiving), siswa dihadapkan pada kasus yaitu saat istrahat dan/atau pergantian jam pelajaran kelas akan menjadi kotor karena sampah kertas, tumpahan air minum, dan lain sebagainya. Berdasarkan pengamatan saat melihat situasi ini, siswa kelas delapan dan sembilan memiliki 
kesadaran untuk mengajak temantemannya membersihkan ruangan kelas dengan menyapu sampah kertas dan membuangnya pada tempat sampah serta mengepel lantai tanpa diajak oleh guru, sedangkan siswa kelas tujuh perlu untuk diajak guru terlebih dahulu untuk membersihkan kelasnya saat kotor. Selain sampah, terkait dengan penggunaan energi listrik (lampu) siswa baik dari kelas tujuh sampai sembilan, sadar untuk selalu mematikan lampu di kelas saat guru selesai menggunakan proyektor dan saat pulang sekolah. Indikator kedua, partisipasi (responding) dimana siswa mampu berinteraksi dengan teman sebaya dan guru yang ditunjukkan lewat mengajak teman untuk membersihkan kelas meskipun bukan tugas piket, menegur teman untuk membuang sampah pada tempatnya, secara spontan membantu guru untuk membersihkan papan tulis dan mematikan lampu dan membuka tirai jendela saat sudah selesai pembelajaran.

Hasil ini menunjukkan bahwa memang perkembangan peserta didik sangat mempengaruhi karakter peduli lingkungan anak. Dibuktikan dari hasil pengamatan dimana bukan hanya siswa perempuan yang bekerja dalam hal penerimaan dan partisipasi saja namun siswa laki-laki pun turut bekerja sama untuk melakukan kedua indikator ini sehingga gender yang adalah status sosial wanita dan pria dalam penelitian ini tidak memberikan dampak yang signifikan terhadap karakter peduli lingkungan siswa SMP.

\section{SIMPULAN DAN SARAN}

\section{Simpulan}

Dari penelitian survei dengan metode kuantitatif deskriptif ini dapat disimpulkan Karakter peduli lingkungan siswa SMP lebih dipengaruhi oleh tingkatan kelas, yang ditunjukkan dengan hasil persentase dan rerata penilaian instrumen NEP yaitu kategori Sangat Baik oleh kelas VII dan IX lebih tinggi dari kelas VIII (22.22\%, 27.27\%, $19.04 \%$ ) sedangkan kategori Tidak Baik, kelas VII dan IX lebih rendah dari kelas VIII $(5.56 \%, 9.09 \%, 9.52 \%)$. Gender hubungannya dengan karakter peduli lingkungan siswa berkorelasi cukup namun tidak signifikan, berdasarkan pengamatan aktivitas siswa dalam menjaga lingkungan sekolahnya yang tidak menunjukkan adanya pengaruh gender. Korelasi yang signifikan antara hubungan gender dan tingkatan kelas terhadap karakter peduli lingkungan siswa, yaitu perempuan kelas VIII dengan kelas IX yang ditunjukkan dari nilai korelasi $\mathrm{r}=0.798$ dengan Sig. 0.017 $<0.05$, sedangkan hasil Pearson pada gender laki-laki dan perempuan dari kelas lain tidak menunjukkan korelasi yang signifikan, sehingga gender tidak dapat dijadikan patokan karakter peduli lingkungan anak, tetapi lebih pada pengaruh pengetahuan, teman sebaya, dan perkembangan diri siswa.

\section{Saran}

Penelitian terkait karakter peduli lingkungan sebaiknya menggunakan variabel uji selain gender seperti pengetahuan, teman sebaya dan 
perkembangan diri siswa, karena melihat dari perkembangan zaman.

\section{DAFTAR PUSTAKA}

Azhar, M., Basyir, D., Alfitri. (2015). Hubungan Pengetahuan Dan Etika Lingkungan Dengan Sikap dan Perilaku Menjaga Kelestarian Llingkungan. Jurnal Ilmu Lingkungan. 13 (1), 36-41

Azwar, S. (2012). Reliabilitas dan Validitas Edisi 4. Yogyakarta: Pustaka Belajar

Dunlap, R.E., Van Liere, K.D., Mertig, A.G., \& Jones, R.E. (2000). Measuring Endorsement of the New Ecological Paradigm: A Revised NEP Scale. Journal of Social Issues. 56 (3), 425-442

Hamzah, S. 2013. Pendidikan Lingkungan : Sekelumit Wawasan Pengantar. Bandung : Refika Aditama

Izzaty, R.E., Suardiman, P.S., Ayriza, Y., Purwandar, Hiryanto, dan Kusmaryani, R.E. (2007). Perkembangan Peserta Didik. Yogyakarta : Universitas Negeri Yogyakarta

Kalantari, K., dan Asadi, A. 2010. Designing a Structural Model for Explaining Environmental Attitude and Behavior of Urban Residents (Case of Tehran). Journal Environmental Research. 4:309320

Kusman, U., Reynolds, R., \& O'Toole, M. (2006). Environmental Beliefs and Attitudes: An Analysis of
Ecological Affinit in Secondari Science Students in Indonesia. Paper at the AARE Annual International Education Research Conference, Adelaide. 27th -30 th November, 2006

Muhammad, J.I., dan Ratnasari, N.G. (2014). Pengaruh Environmental Knowledge, Environmental Attitude, Government Initiative, Peer Pressure Dan Eco Label Pada Green Purchase Intention Konsumen Indonesia. Studi Kasus The Body Shop Indonesia. Jakarta : Universitas Indonesia

Mujahidah. (2015). Implementasi Teori Ekologi Brofen Brenner dalam Membangun Pendidikan Karakter yang Membangun Pendidikan Karakter yang Berkualitas. Jurnal Lentera. 17 (2), 171 - 185

Papalia, D. E., Olds, S.W., dan Feldman, R.D. (2008). Psikologi Perkembangan. Jakarta : Kencana Prenada Media Group

Purnomo, P.N. (2014). Analisis Pengaruh Pengetahuan Lingkungan Terhadap peilaku Ekologi Dengan Gneder Sebagai Variabel Moderasi. [Artikel Publikasi Ilmiah]. Surakarta : UMS

Septian, Y. (2016). Perilaku Ramah Lingkungan Peserta Didik SMA. Social Science Education Journal. 3(2), $193-201$

Subali, B. (2012). Prisnsip Assessmen \& Evaluasi Pembelajaran. Yogyakarta: UNY Press 
Sudarsono. (2013). Metode Penelitian Pendidikan. Yogyakarta : UNY Press

Sudjana. (2005). Metoda Statistika. Bandung : Tarsito

Suhardin. (2016). Pengaruh Perbedaan Jenis Kelamin dan Pengetahuan Tentang Konsep Dasar Ekologi terhadap Kepedulian Lingkungan : Studi Expost Facto di SMA Negeri 7 Depok Tahun 2015. Edukasi: Jurnal Penelitian Pendidikan Agama dan Keagaman. 14(1), 117 $-132$

Tamara, R.M. (2016). Peranan Lingkungan Sosial Terhadap Pembentukan Sikap Peduli Lingkungan Peserta Didik Di SMA Negeri Kabupatern Cianjur. Jurnal Pendidikan Geografi. 16(1), $44-55$

Yunianto, A.E. (2013). Penerapan Hasil Belajar Kimia Makanan Mahasiswa Prodi Pendidikan Tata Boga Pada Pemilihan Makanan Kemasan. http://repository.upi.edu/4269/6/S_ PKK_0806613_Chapter3.pdf/.

Diakses tanggal 25 Mei 2017

\section{PROFIL SINGKAT}

Lovely Ezverenzha Lelatobur, lahir di kota Ambon, Maluku 25 Juni 1995. Mahasiswa double degree pada Fakultas Biologi, program studi Biologi dan Pendidikan Biologi, Universitas Kristen Satya Wacana Salatiga. Untuk degree pada progdi Biologi telah diselesaikan pada tahun 2016. Aktivitas yang dilakukan setelah lulus dari progdi Biologi adalah melanjutkan studi pada progdi Pendidikan Biologi dan dalam tahap menyelesaikan tugas akhir (skripsi). 